\title{
Microbial carbon use efficiency: accounting for population, community, and ecosystem-scale controls over the fate of metabolized organic matter
}

\author{
Kevin M. Geyer • Emily Kyker-Snowman • \\ A. Stuart Grandy - Serita D. Frey
}

Received: 26 June 2015/ Accepted: 25 January 2016/Published online: 9 February 2016

(C) The Author(s) 2016. This article is published with open access at Springerlink.com

\begin{abstract}
Microbial carbon use efficiency (CUE) is a critical regulator of soil organic matter dynamics and terrestrial carbon fluxes, with strong implications for soil biogeochemistry models. While ecologists increasingly appreciate the importance of CUE, its core concepts remain ambiguous: terminology is inconsistent and confusing, methods capture variable temporal and spatial scales, and the significance of many fundamental drivers remains inconclusive. Here we outline the processes underlying microbial efficiency and propose a conceptual framework that structures the definition of CUE according to increasingly broad temporal and spatial drivers where (1) $C U E_{P}$ reflects population-scale carbon use efficiency of microbes governed by species-specific metabolic and thermodynamic constraints, (2) $C U E_{C}$ defines community-scale microbial efficiency as gross
\end{abstract}

Responsible Editor: Sharon A. Billings.

K. M. Geyer $(\bowtie)$ · E. Kyker-Snowman ·

A. S. Grandy - S. D. Frey

Department of Natural Resources \& the Environment,

University of New Hampshire, Durham, NH 03824, USA

e-mail: kevin.geyer@unh.edu

E. Kyker-Snowman

e-mail: ek2002@wildcats.unh.edu

A. S. Grandy

e-mail: stuart.grandy@unh.edu

S. D. Frey

e-mail: serita.frey@unh.edu biomass production per unit substrate taken up over short time scales, largely excluding recycling of microbial necromass and exudates, and (3) $C U E_{E}$ reflects the ecosystem-scale efficiency of net microbial biomass production (growth) per unit substrate taken up as iterative breakdown and recycling of microbial products occurs. $\mathrm{CUE}_{\mathrm{E}}$ integrates all internal and extracellular constraints on CUE and hence embodies an ecosystem perspective that fully captures all drivers of microbial biomass synthesis and decay. These three definitions are distinct yet complementary, capturing the capacity for carbon storage in microbial biomass across different ecological scales. By unifying the existing concepts and terminology underlying microbial efficiency, our framework enhances data interpretation and theoretical advances.

Keywords Carbon use efficiency $\cdot$ Microbial metabolism - Carbon cycling · Microbial ecology

\section{Introduction}

The efficiency with which microorganisms convert available organic substrates into stable, biosynthesized products (broadly defined as 'carbon use efficiency'-CUE) is a critical step in ecosystem carbon cycling. Microbes metabolize a wide variety of compounds to satisfy heterotrophic demands for carbon (C) and energy, thereby influencing the 
accumulation/loss dynamics of soil organic matter stocks and ecosystem carbon dioxide efflux (Frey et al. 2013; Karhu et al. 2014). CUE is therefore an important concept for understanding the future trajectory of soil-climate feedbacks, recognition of which has led to recent reviews of the topic (Manzoni et al. 2012; Sinsabaugh et al. 2013), application in ecosystem models (Wang et al. 2013; Allison 2014; Wieder et al. 2014), and the development of new methods to estimate microbial efficiency in environmental samples (Blazewicz and Schwartz 2011; Dijkstra et al. 2011b; Herrmann et al. 2014). However, progress in this field is hampered by chronic issues symptomatic of a divide among research approaches and disciplinespecific terminologies. A common, interdisciplinary framework is needed to unite these current perspectives.

The relevance of CUE spans scales ranging from a single microbial cell to entire ecosystems. For example, variation in CUE has been linked to substrate biochemistry (Linton and Stephenson 1978; Payne and Wiebe 1978; Lemee et al. 2002), thermodynamic and genetic capacity of the cell (Roller and Schmidt 2015), the environmental sensitivity of microbial physiology (Apple et al. 2006; Schipper et al. 2014), consumersubstrate stoichiometric balance (Creamer et al. 2014; Mooshammer et al. 2014), and microbial community structure and activity (Six et al. 2006; Blagodatskaya et al. 2014). Other approaches have meanwhile explored CUE from food web and ecosystem perspectives, such as the effects of altered efficiency on availability of resources to higher trophic levels [i.e., Lindeman's ecological efficiency (1942)] and the mediation of ecosystem services like $\mathrm{C}$ sequestration (Frey et al. 2013). CUE is thus increasingly recognized by microbiologists, ecologists, and modelers alike as essential for understanding the causes and consequences of microbial $\mathrm{C}$ cycling.

The drawbacks of such wide-ranging approaches to measure and interpret CUE become evident after only a brief introduction to the literature. Numerous habitat-specific (and even laboratory-specific) methods for quantifying CUE have emerged to accommodate the challenges of working within specific systems (e.g., pure cultures, soil, and water), yet rarely are these methods developed with cross-site synthesis in mind. The wide range of published efficiency estimates produced by these many techniques (Manzoni et al. 2012) suggests that methodological differences and limitations remain underexplored (Sinsabaugh et al. 2013). Unstandardized and poorly defined terminology further compounds these problems by making methods, conceptual advances, and conclusions difficult to compare among studies. Collectively, these problems inhibit a more synthetic understanding of microbial contributions to $\mathrm{C}$ cycling that integrates evidence from cellular to ecosystem scales.

At its core, CUE reflects a collection of numerous processes (some physiological, others characteristic of community or ecosystem dynamics) that influence $\mathrm{C}$ metabolism across varying scales of time and space. We establish here a conceptual model that honors and organizes this existing complexity by conceptualizing CUE as a hierarchy of increasingly broad temporal and spatial drivers of efficiency. In doing so, our approach distills important aspects of CUE (i.e., techniques, vocabularies, published estimates) with the goal of enhancing the interpretation and application of CUE data. Specifically, we:

(1) Synthesize the major processes that affect microbial metabolism of organic $\mathrm{C}$ at physiological and ecological scales using a standardized terminology.

(2) Structure these processes into a unifying model of CUE such that three nested definitions emerge from the literature- $\mathrm{CUE}_{\mathrm{P}(\mathrm{OPULATION})}$, $\mathrm{CUE}_{\mathrm{C}(\mathrm{OMMUNITY})}$, and $\mathrm{CUE}_{\mathrm{E}(\mathrm{COSYSTEM})}$.

(3) Review research directions that will advance our current understanding of CUE.

Synthesizing the physiological and ecological basis of carbon use efficiency

Many of the problems that prevent broader synthesis of CUE concepts into a comprehensive framework stem from confusion concerning the factors that influence efficiency and the terminology used to describe them. For example, 'assimilation' is a term regularly used synonymously with 'uptake' or 'biomass production' even though all are distinct physiological processes (described below). Here we outline the major processes essential to $\mathrm{C}$ metabolism (from initial substrate uptake through biomass synthesis and turnover) for an individual microbial cell using a consistent terminology (Fig. 1). Key terms are highlighted in bold text throughout the following discussion and are defined in Table 1. CUE is used here only 


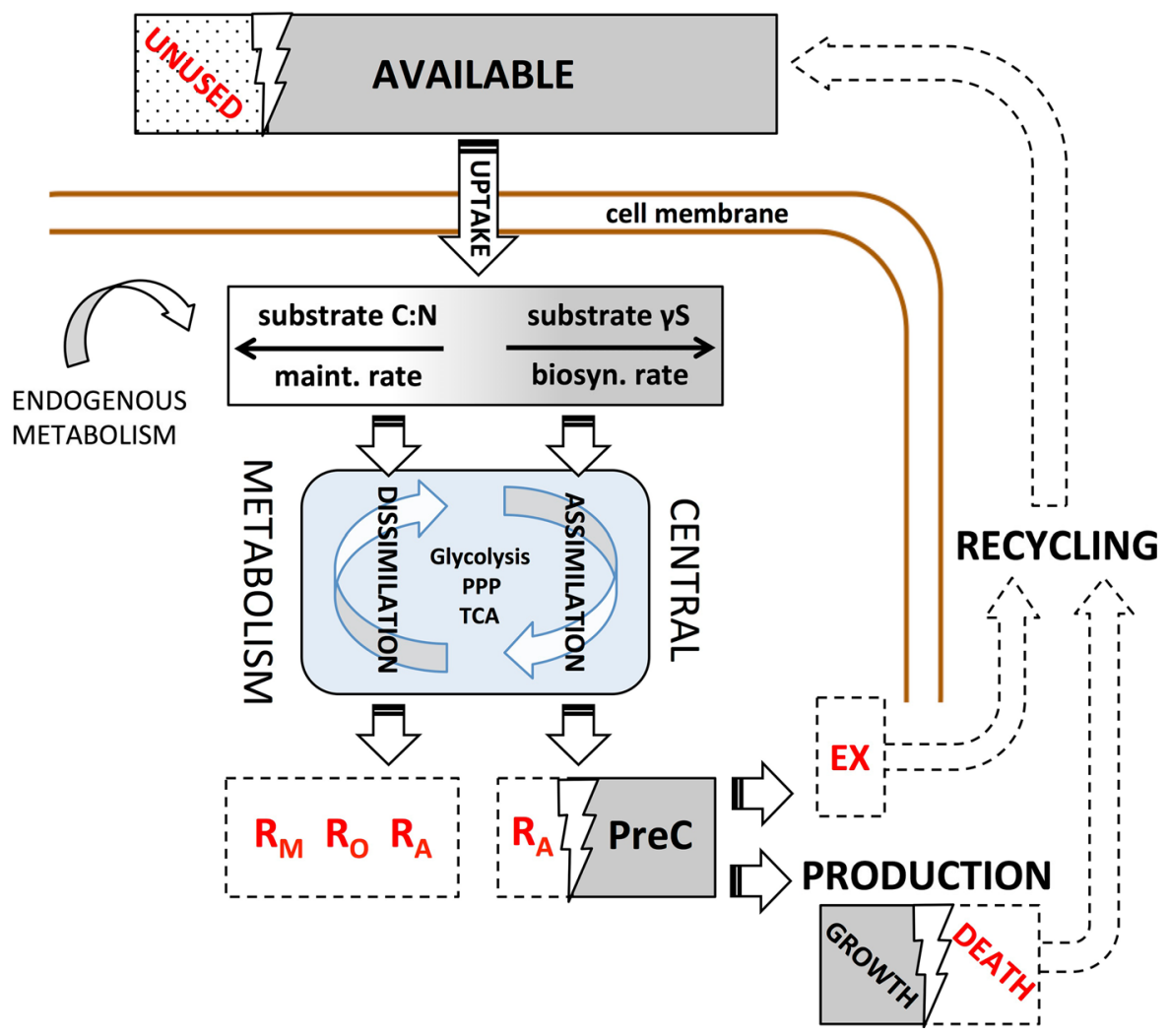

Fig. 1 Diagram of the carbon pools (boxes) and fluxes (arrows) associated with microbial metabolism. Substrate reduction $(\gamma \mathrm{S})$ and biosynthesis rate positively influence assimilatory demand, while substrate $\mathrm{C}: \mathrm{N}$ and maintenance rate positively influence dissimilatory demand. Central metabolism is simplified as glycolysis, the pentose phosphate pathway (PPP), and tricarboxylic acid cycle (TCA). Maintenance $\left(\mathrm{R}_{\mathrm{M}}\right)$ and overflow $\left(\mathrm{R}_{\mathrm{O}}\right)$ respiration are prioritized during dissimilation; a transition to

in reference to that portion of $\mathrm{C}$ brought into the cell (i.e., uptake $\mathrm{C}$ ) which a microorganism retains as microbial biomass. As a result, CUE is sensitive to extracellular forces that inhibit or promote recycling and reuse of microbial products and necromass but does not quantify stabilization of $\mathrm{C}$ outside the cell [e.g., humus yield; (Paustian et al. 1995)].

Uptake of substrates is the first step by which microorganisms internally process organic matter. Substrates are primarily directed towards central metabolism through the linked processes of glycolysis and the tricarboxylic acid cycle, although intracellular storage prior to metabolism is an alternative fate that remains poorly understood (Payne and Wiebe 1978; Frey et al. 2001). Assuming that a metabolic demand for carbon and/or energy exists, central metabolism respiration in support of anabolism $\left(\mathrm{R}_{\mathrm{A}}\right)$ will occur if sufficient resources exist. Grey boxes represent pools of organic matter retaining the potential for use in growth; open boxes represent metabolic carbon losses from the cell (e.g., EX, exudates); stippling indicates organic matter unused for microbial uptake. Lightning bolts indicate pools divisible into subpools that may vary in relative size depending on soil and metabolic conditions (see text for further discussion)

proceeds to either dissimilate or assimilate the substrate depending on various conditions (Neidhardt et al. 1990; Kim and Gadd 2008). Dissimilation maximizes the catabolic harvesting of energy and thus occurs preferentially when energy demands are high or energy limitation exists (Pirt 1965; Roels 1980; Gommers et al. 1988; Lemee et al. 2002; Fonte et al. 2013). Energy demands include non-growth maintenance activities (maintenance respiration, $\mathrm{R}_{\mathrm{M}}$ ) like motility, osmoregulation, and the molecular turnover of proteins and nucleic acids (Russell and Cook 1995; Wang and Post 2012). Nutrient limited cells also direct resources towards dissimilation; under these conditions, organisms mine organic matter via inefficient, carbon-spilling respiratory mechanisms (overflow respiration, $\mathrm{R}_{\mathrm{O}}$ ) in search of nitrogen, phosphorus, or 
Table 1 Description of terms found in Fig. 1 and throughout this article

\begin{tabular}{|c|c|c|c|}
\hline Term & Definition & Derivation & Measurement \\
\hline Uptake & $\begin{array}{l}\text { Amount of organic substrate taken up } \\
\text { for microbial functioning, including } \\
\text { respiration and biosynthesis }\end{array}$ & $\mathrm{UPTAKE}=\mathrm{R}_{\mathrm{T}}+\mathrm{EX}+\mathrm{PROD}$ & $\begin{array}{l}\text { Methodology Measured change in } \\
\text { organic substrate concentration } \\
\text { external to biomass }{ }^{\mathrm{a}} \text { or inferred from } \\
\text { sum of total respiration and } \\
\text { production }\left(\mathrm{R}_{\mathrm{T}}+\mathrm{PROD}\right) \\
\text { Notes Some portion of measured uptake } \\
\text { may be substrate that "disappeared" } \\
\text { due to any force preventing detection } \\
\text { (e.g., sorption to mineral surfaces) }\end{array}$ \\
\hline Dissimilation & $\begin{array}{l}\text { Complete substrate mineralization } \\
\text { within central metabolism for the } \\
\text { generation of energy equivalents }\end{array}$ & DISSIM $=\mathrm{R}_{\mathrm{M}}+\mathrm{R}_{\mathrm{O}}+\mathrm{R}_{\mathrm{A}}$ & $\begin{array}{l}\text { Methodology Respiration for } \\
\text { maintenance requirements }\left(\mathrm{R}_{\mathrm{M}}\right) \text {, } \\
\text { during overflow metabolism }\left(\mathrm{R}_{\mathrm{O}}\right) \text {, and } \\
\text { to supplement anabolic }\left(\mathrm{R}_{\mathrm{A}}\right) \\
\text { requirements } \mathrm{b}, \mathrm{c} \\
\text { Notes DISSIM is the predominant } \\
\text { pathway of carbon respiration during } \\
\text { low biosynthesis and composes a } \\
\text { diminishing portion of respiratory loss } \\
\text { with increasing biosynthesis rates }\end{array}$ \\
\hline Assimilation & $\begin{array}{l}\text { Partial substrate mineralization within } \\
\text { central metabolism for the } \\
\text { generation of energy equivalents, } \\
\text { and partial generation of precursor } \\
\text { (PreC) compounds }\end{array}$ & $\mathrm{ASSIM}=\mathrm{R}_{\mathrm{A}}+$ PreC & $\begin{array}{l}\text { Methodology Respiration to support } \\
\text { anabolism }\left(\mathrm{R}_{\mathrm{A}}\right) \text { of substrate } \mathrm{e}^{\mathrm{c}, \mathrm{d}} \text { and } \\
\text { generation of precursor compounds } \\
\text { used in biosynthesis } \\
\text { Notes ASSIM is the predominant } \\
\text { pathway of carbon respiration during } \\
\text { high biosynthesis as DISSIM (e.g., } \\
\mathrm{R}_{\mathrm{M}} \text { ) becomes a diminishing relative } \\
\text { requirement }\end{array}$ \\
\hline $\mathrm{R}_{\mathrm{T}}$ & Total carbon mineralized & $\mathrm{R}_{\mathrm{T}}=\mathrm{R}_{\mathrm{M}}+\mathrm{R}_{\mathrm{O}}+\mathrm{R}_{\mathrm{A}}$ & $\begin{array}{l}\text { Methodology Total respiratory losses, as } \\
\text { measured by } \mathrm{CO}_{2} \text { production or } \mathrm{O}_{2} \\
\text { demand }^{\mathrm{g}, \mathrm{h}}\end{array}$ \\
\hline PreC & $\begin{array}{l}\text { Precursor carbon compounds } \\
\text { generated during assimilation }\end{array}$ & PreC $=\mathrm{EX}+\mathrm{PROD}$ & Methodology Metabolic flux analysis ${ }^{\mathrm{i}}$ \\
\hline EX & $\begin{array}{l}\text { Exudation of enzymes and other } \\
\text { metabolites created from PreC }\end{array}$ & $\mathrm{EX}=\mathrm{PreC}-\mathrm{PROD}$ & $\begin{array}{l}\text { Methodology Few methods exist for } \\
\text { measuring exudation rates. } \\
\text { Spectrophotometry has been used with } \\
\text { cultured samples } \\
\text { Notes Synthesis of metabolites from } \\
\text { PreC assumes no pre-existing biomass } \\
\text { is used in metabolite generation }\end{array}$ \\
\hline Production & $\begin{array}{l}\text { Gross biomass production, created } \\
\text { using PreC }\end{array}$ & $\mathrm{PROD}=\mathrm{UPTAKE}-\mathrm{R}_{\mathrm{T}}-\mathrm{EX}$ & $\begin{array}{l}\text { Methodology Short-term gross } \\
\text { biosynthesis measured from changing } \\
\text { cell densities }{ }^{\mathrm{k}} \text { or incorporation of } \\
\text { (often) labeled carbon substrates (e.g., } \\
{ }^{13} \mathrm{C} \text {-glucose) }{ }^{1} \text {, growth intermediates } \\
\left(\text { e.g., }{ }^{3} \mathrm{H} \text {-leucine) }{ }^{\mathrm{m}, \mathrm{n}} \text {, or water (e.g. }\right. \\
\left.\mathrm{H}_{2}^{18} \mathrm{O}\right)^{\mathrm{o}} \\
\text { Notes Short incubation times avoid } \\
\text { effects of biomass turnover, recycling, } \\
\text { and other extracellular influences on } \\
\text { net growth. By definition, gross } \\
\text { production is greater than or equal to } \\
\text { zero }\end{array}$ \\
\hline
\end{tabular}


Table 1 continued

\begin{tabular}{llll}
\hline Term & Definition & Derivation & Measurement \\
\hline Death & $\begin{array}{c}\text { Turnover of biomass caused by many } \\
\text { processes (e.g., microbivory, natural } \\
\text { cell death) }\end{array}$ & DEATH = PROD - GROWTH & $\begin{array}{c}\text { Methodology Direct measures lacking, } \\
\text { although inferred from (PROD }- \\
\text { GROWTH) } \\
\text { Notes By definition, death is greater } \\
\text { than or equal to zero }\end{array}$ \\
& Net biomass production & GROWTH = UPTAKE $-\mathrm{R}_{\mathrm{T}}-\begin{array}{c}\text { Methodology Measurable using same } \\
\text { methods as for PROD, but with longer } \\
\text { period of observation }\end{array}$ \\
& EX - DEATH & $\begin{array}{c}\text { Notes Long incubation times integrate } \\
\text { effects of biomass turnover, recycling, } \\
\text { and other extracellular influences on } \\
\text { biosynthesis }\end{array}$
\end{tabular}

Dissimilation refers to the catabolism of organic substrates in central metabolism strictly for the generation of energy equivalents (e.g., NADH, NADPH2, ATP). Assimilation refers to the paired catabolism and anabolism of organic substrates in central metabolism for the generation of energy equivalents and the precursor carbon compounds (PreC) used in biosynthesis. Biosynthesis is the anabolic process of generating microbial biomass from PreC

a Frey et al. (2001)

b Manzoni et al. (2012)

c Wang and Post (2012)

d Gommers et al. (1988)

e Kim and Gadd (2008)

f Zhang and Lynd 2005)

g Bott (2006)

h Brant et al. (2006)

i Tang et al. (2009)

${ }^{j}$ Kredics et al. (2000)

k Keiblinger et al. (2010)

1 Frey et al. (2013)

m Alden et al. (2001)

${ }^{n}$ Ward (2006)

o Blazewicz and Schwartz (2011)

other nutrients (Russell and Cook 1995; Manzoni et al. 2008; Sinsabaugh et al. 2013; Creamer et al. 2014; Mooshammer et al. 2014). Finally, C may be dissimilated to support anabolic energy requirements for biosynthesis (anabolic respiration, $\mathrm{R}_{\mathrm{A}}$; note the term "biosynthesis" is used throughout to describe the synthesis, polymerization, and assembly reactions that lead to creation of new biomass). CUE is theoretically zero during dissimilation as all $\mathrm{C}$ is ultimately respired, thus explaining the low CUE of organisms experiencing conditions of minimal growth, limited/ poor quality resources, and nutrient stress.

Assimilation occurs under conditions more favorable to biosynthesis such as high resource quality or nutrient abundance. Assimilation is characterized by both catabolic and anabolic processes that, respectively, generate the energy equivalents (anabolic respiration, $\mathrm{R}_{\mathrm{A}}$ ) and precursor carbon compounds (PreC) necessary for biosynthesis. These precursor compounds are siphoned away from central metabolism as pathway intermediates for incorporation into cell structures using the energy generated from both dissimilation and assimilation (Kim and Gadd 2008). Regardless of conditions, assimilation only occurs after non-growth requirements have been satisfied and sufficient excess $\mathrm{C}$ and energy are available (Dawes and Ribbons 1964; Ingraham et al. 1983; Kim and Gadd 2008). As a consequence, an increase in 
assimilation and growth rates caused by increased substrate availability or the degree of substrate reduction positively affects CUE by reducing the relative amount of dissimilation needed to support maintenance. Assimilation has inherent respiratory losses $\left(\mathrm{R}_{\mathrm{A}}\right)$, however, that limit maximum efficiency to $\sim 0.85$ for even the most reduced compounds (Gommers et al. 1988).

In summary, any environmental or biological factor that influences the relative amount of substrate assimilation or dissimilation will have a significant effect on CUE. Factors such as resource quantity and quality (e.g., C:N ratio, degree of substrate reduction) behave as "top-down" regulators by constraining the overall availability of energy and $\mathrm{C}$, and thus the potential for biosynthesis. Meanwhile, a variety of "bottom-up" controls influence biosynthesis rates, and indirectly CUE, by affecting demand for PreC downstream of central metabolism (e.g., in organelles or cellular space where assembly of macromolecules occurs). For example, increasing temperature may increase efficiency by inducing assimilatory demand to sustain higher rates of biosynthesis (Pirt 1965; Linton and Stephenson 1978; Gommers et al. 1988) or, alternatively, decrease CUE if dissimilatory demands increase (Rivkin and Legendre 2001) because of higher rates of $R_{M}$ (Marr et al. 1963). Maximum CUE should be achieved when both top-down and bottomup forces work in concert, such as conditions where abundant, high quality resources are available and environmental cues (e.g., temperature, $\mathrm{pH}$, community dynamics) are most conducive to biosynthesis.

Biosynthesis using precursor compounds produces new biomass, macromolecules to replace those that are degraded (i.e., molecular turnover), and a variety of metabolites destined for secretion (i.e., exudates; EX). Molecular turnover is traditionally considered a form of cellular maintenance while exudates like exoenzymes are considered a metabolic loss (Manzoni et al. 2012). Gross biomass production, on the other hand, is foundational to the concept of CUE when defined as the ratio of microbial production to the sum of production and respiration (del Giorgio and Cole 1998). Numerous processes occur beyond this stage of substrate breakdown, however, with important effects on CUE. For example, turnover of microbial biomass following cell death will reduce estimates of gross microbial production (defined here as production) into net production (defined here as growth). Extracellular recycling of microbial necromass and exudates will then create feedbacks into the pool of available organic matter, thus making the interaction between recycled organic matter and the environmental matrix of water and/or minerals critically important (Bol et al. 2009; Grandy et al. 2009; Cotrufo et al. 2013).

Under certain conditions substrate availability cannot support biosynthesis and cell integrity can only be maintained by the metabolism of internal substrates like cellular proteins and nucleic acids or storage compounds. Endogenous metabolism can be significant in these cases (Russell and Cook 1995). The efficiency of an organism undergoing endogenous metabolism is largely unexplored, particularly regarding the transition between states of activity and dormancy that may be triggered by resource supplies. Such circumstances may well characterize a significant portion of microbial life history where resource availability is limited across space or time (del Giorgio and Cole 1998) and require further investigation. Our discussion also assumes that oxygen concentrations are optimum for microbial biosynthesis. Hypoxia may induce a shift from cellular respiration to generally less efficient fermentation (Pfeiffer et al. 2001; Lipson et al. 2009).

A unified conceptual framework for interpreting microbial efficiency

The preceding discussion reveals two specific challenges that influence how we interpret CUE data: the processes foundational to efficiency (1) vary in importance depending on the ecological scale of inference (population, community, ecosystem) and (2) become important at different stages of substrate breakdown. For example, short-term observations of CUE may emphasize the role of substrate uptake and maintenance respiration, while longer-term observations may be necessary to adequately capture the impact of substrate recycling. Because existing techniques for estimating CUE differ in the ecological and temporal scales they integrate, they often describe very different aspects of CUE. This could explain much of the variation in published CUE estimates that have been documented from culture-based, soil, and aquatic systems (Six et al. 2006; Manzoni et al. 2012).

Our conceptual model organizes microbial CUE as three nested definitions: $\mathrm{CUE}_{\mathrm{P}}, \mathrm{CUE}_{\mathrm{C}}$, and $\mathrm{CUE}_{\mathrm{E}}$ (Fig. 2). Each of these terms is associated with 
existing methods that estimate the influence of a unique suite of drivers on CUE at increasingly broad ecological scales. $\mathrm{CUE}_{\mathrm{P}}$ describes the metabolic limits to carbon use efficiency intrinsic to a population of cells, most readily measured using pure cultures (Marr et al. 1963; Pirt 1965; Gommers et al. 1988). Naturally occurring aquatic or terrestrial microbial communities encounter additional drivers that may directly or indirectly affect CUE. CUE $\mathrm{C}_{\mathrm{C}}$ integrates these effects as the carbon use efficiency leading to gross microbial biomass production. Because methods for estimating $\mathrm{CUE}_{\mathrm{C}}$ conventionally attempt to avoid factors that detract from gross production (e.g., biomass turnover), they are unreliable indicators of longer-term net stabilization of uptake $\mathrm{C}$ as microbial biomass. $\mathrm{CUE}_{\mathrm{E}}$ is used here as the most inclusive definition of efficiency that incorporates ecosystem-scale forces controlling net dynamics of microbial biomass. Below we expand on these concepts and their relevance to researchers working in aquatic and soil systems using a variety of techniques.
$C U E_{P}$

Microbiologists in the 1950s adopted continuousculturing (chemostat) techniques to closely examine species-specific CUE dynamics (Russell and Cook 1995). Efficiency is described in this context as the biomass yield from either a quantity of available catabolic ATP ( $\left.\mathrm{Y}_{\text {ATP }}\right)$ or mass of available substrate (Y YUBSTRATE). These measurements, typically made under optimal biosynthetic conditions, can produce estimates of efficiency that approach theoretical maxima $\left(\mathrm{Y}_{\mathrm{G}}\right.$, true growth yield; Pirt 1965) and are constrained only by thermodynamic and metabolic limits to efficiency. Combining a chemostat approach with isotopic enrichment $\left({ }^{13} \mathrm{C}\right.$ metabolic flux analysis) can also provide estimation of metabolic PreC generation and biomass yield (Tannler et al. 2008; Tang et al. 2012). For pure cultures grown aerobically on non-limiting supplies of glucose, yield is typically $\sim 0.6$, although higher estimates approaching $\sim 0.85$ have been observed for more reduced substrates and

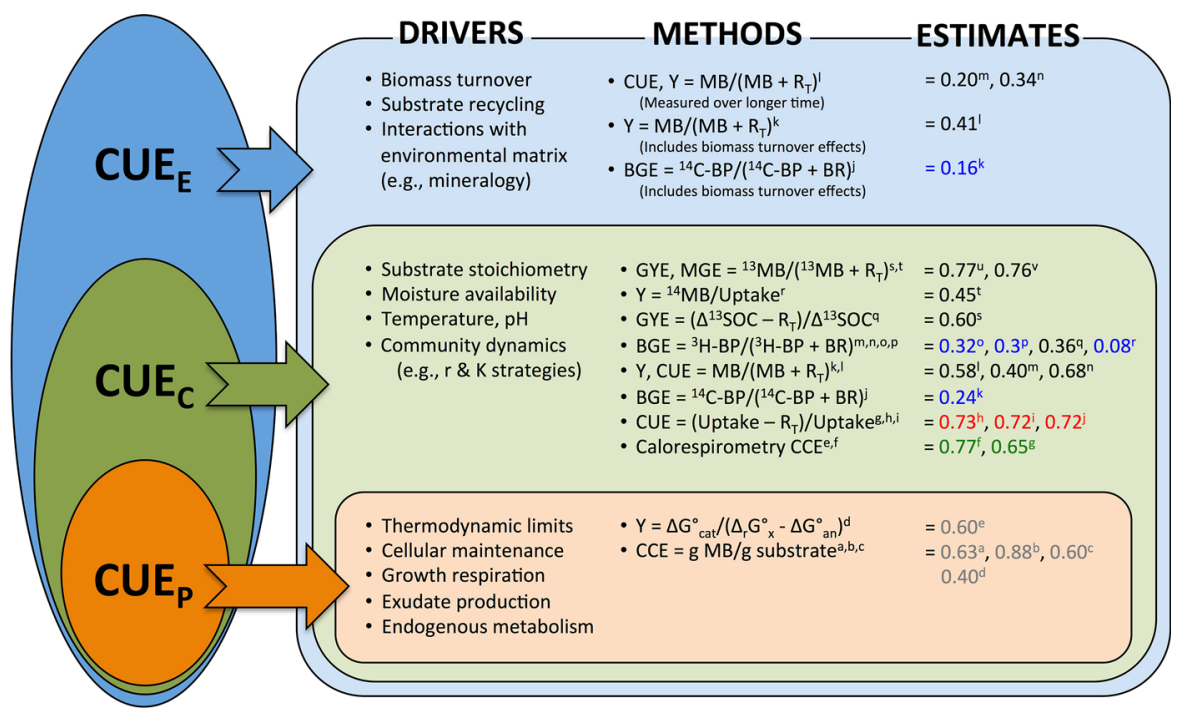

Fig. 2 The nested tiers of carbon use efficiency and the significant drivers at each scale of inquiry. Common methods and published estimates of efficiency associated with these levels are provided using the citing authors' original terminology in order to highlight the diversity of terminology used throughout the literature. Estimates are color coded by the type of sample analyzed: soil (black), water (blue), isotopologues in soil (red), calorespirometry in soil (green) and culture-based/thermodynamics (grey). $\mathrm{CUE}_{\mathrm{P}}$ examples depict glucose (or similar) amendment. $C U E$ carbon use efficiency, $Y$ yield, $M B$ microbial biomass, $R$ respiration, $B G E$ bacterial growth efficiency, $B P$ bacterial production, $B R$ bacterial respiration, $M G E$ microbial growth efficiency, SOC soil organic carbon, $C C E$ carbon conversion efficiency, $\Delta \mathrm{G}^{\circ}$ cat, Gibbs energy of catabolism; $\Delta_{\mathrm{r}} \mathrm{G}^{\circ}{ }_{\mathrm{x}}$, Gibbs energy of growth; $\Delta \mathrm{G}^{\circ}{ }_{\text {an }}$, Gibbs energy of anabolism. ${ }^{\mathrm{a}}$ Linton and Stephenson (1978), ${ }^{\mathrm{b}}$ Gommers et al. (1988), ${ }^{\mathrm{c}}$ Babel (2009), ${ }^{\mathrm{d}}$ Tannler et al. (2008), ${ }^{\mathrm{e}}$ von Stockar et al. (2006), ${ }^{\mathrm{f}}$ Barros et al. (2010), ${ }^{\mathrm{g}}$ Harris et al. (2012), ${ }^{\mathrm{h}}$ Dijkstra et al. (2011c), ${ }^{\mathrm{i}}$ Dijkstra et al. (2011b), ${ }^{\mathrm{j}}$ Hagerty et al. (2014), ${ }^{\mathrm{k}} \mathrm{Ram}$ et al. (2003), ${ }^{\mathrm{l}}$ Frey et al. (2001), ${ }^{\mathrm{m}}$ Blagodatskaya et al. (2014), ${ }^{\mathrm{n}}$ Elliott et al. (1983), ${ }^{\mathrm{O}}$ Apple and del Giorgio (2007), ${ }^{\mathrm{p}}$ Kosolapov et al. (2014), ${ }^{\mathrm{q}}$ Lee and Schmidt (2014), ${ }^{\mathrm{r}}$ Ortega-Retuerta et al. (2012), ${ }^{\text {s}}$ Thiet et al. (2006), ${ }^{\mathrm{t}}$ Lipson et al. (2009), ${ }^{\mathrm{u}}$ Brant et al. (2006), 'Frey et al. (2013). (Color figure online) 
more efficient organisms (Linton and Stephenson 1978; Gommers et al. 1988; Babel 2009). Examining the efficiency of individual microbial species in situ is technically infeasible and so culture-based methods remain the standard for measuring carbon use efficiency of populations $\left(\mathrm{CUE}_{\mathrm{P}}\right)$.

Important drivers of $\mathrm{CUE}_{\mathrm{P}}$ include maintenance respiration rates, biosynthesis rates, and exudate generation. These can vary predictably by species, allowing classification of taxa as $\mathrm{r}$ - or K-strategists assuming a tradeoff exists between catabolic rate and yield (Angulo-Brown et al. 1995; Pfeiffer et al. 2001). Relatively rapid substrate utilization and biosynthesis rates would be a competitive advantage for $\mathrm{r}$-strategists despite low overall CUE when conditions are C-rich; however, K-strategists would become favored when substrate is limiting. Bacteria and fungi have been broadly classified as $\mathrm{r}$ - and $\mathrm{K}$-strategists, respectively, due to their anticipated average relative growth rates and CUE (Rousk and Baath 2007; Lipson et al. 2009; Keiblinger et al. 2010; Reischke et al. 2014), although efficient bacteria and inefficient fungi likely also exist. While $\mathrm{CUE}_{\mathrm{P}}$ is a trait that differs among microbial species, it remains positively correlated with substrate availability and biosynthesis rate for any single species.

\section{$C U E_{C}$}

Although cultured laboratory populations have provided much valuable information regarding the physiological basis of efficiency, complex aquatic and soil microbial communities encounter many additional factors that influence CUE. These drivers include the bioavailability of $\mathrm{C}$ and energy (Linton and Stephenson 1978; Bremer and Kuikman 1994; Fonte et al. 2013), the sensitivity of growth rates to environmental fluctuations in, for example, temperature (Apple et al. 2006; Amado et al. 2013; Frey et al. 2013; Schipper et al. 2014), consumer-substrate stoichiometric balance (Rousk and Baath 2007; Creamer et al. 2014; Mooshammer et al. 2014), and microbial community dynamics (Six et al. 2006; Lipson et al. 2009; Blagodatskaya et al. 2014). Numerous approaches to measuring community-scale carbon use efficiency $\left(\mathrm{CUE}_{\mathrm{C}}\right)$ exist using a ratio of biomass production and substrate uptake, where uptake can be approximated by the sum of production and respiration (Manzoni et al. 2012). These methods often employ short-term incubations (often less than $3 \mathrm{~h}$, but up to $\sim 48 \mathrm{~h}$ ) of a sample after amendment with an unlabeled (Devevre and Horwath 2000; Frey et al. 2001; Tiemann and Billings 2011) or isotopically-labeled substrate (e.g., ${ }^{13} \mathrm{C}$-glucose, ${ }^{14} \mathrm{C}$-acetate, ${ }^{3} \mathrm{H}$-thymidine) (Fuhrman and Azam 1980; Cole et al. 1988; Alden et al. 2001; Brant et al. 2006; Dijkstra et al. 2011a; Frey et al. 2013). Given these shared characteristics, we use ' $\mathrm{CUE}_{\mathrm{C}}$ ' as an umbrella term to organize all approaches that express the capacity for mixed microbial communities to utilize substrates for gross production over short periods before significant biomass turnover (Table 2). $\mathrm{CUE}_{\mathrm{C}}$ thus eliminates the need for redundant terms like microbial growth efficiency, growth yield efficiency, yield, bacterial growth efficiency, and carbon conversion efficiency (Fig. 2).

$\mathrm{CUE}_{\mathrm{C}}$ methods use relatively short incubations focusing on primary metabolism of a substrate before substantial recycling of necromass and exudates can occur. Indeed, isotopic labeling experiments have shown a rapid increase in the labeled portion of microbial biomass immediately after isotope amendment, followed by a stationary or declining phase (Brant et al. 2006; Blazewicz and Schwartz 2011; Reischke et al. 2014). These results suggest that isotopes track the initial generation and proliferation of nascent cells in the first hours post-amendment, followed by the net balance between production and biomass turnover over longer periods. Isotope-based techniques are generally preferable to unlabeled approaches because smaller substrate additions can be used that do not greatly enrich the available pool of organic matter. Labeled substrates also permit measurement of native soil organic matter priming, the mineralization of which would inflate respiration rates and underestimate CUE.

Based on the vocabulary developed here, the mathematical definition of $\mathrm{CUE}_{\mathrm{C}}$ is (Eq. 1)

$$
\begin{aligned}
\mathrm{CUE}_{\mathrm{C}} & =\text { Production } / \text { Uptake }=\left(\text { Uptake }-\mathrm{R}_{\mathrm{T}}-\mathrm{EX}\right) / \text { Uptake } \\
& =\text { Production } /\left(\text { Production }+\mathrm{R}_{\mathrm{T}}+\mathrm{EX}\right),
\end{aligned}
$$

such that $\mathrm{CUE}_{\mathrm{C}}$ is the quotient of gross microbial biomass production and the sum of gross production, total respiration $\left(\mathrm{R}_{\mathrm{T}}\right)$, and exudates $(\mathrm{EX})$. Important aspects of this formula include (1) the inclusion of an EX term that is dependent on whether exudate 
Table 2 A summary of characteristics distinguishing community-scale carbon use efficiency $\left(\mathrm{CUE}_{\mathrm{C}}\right)$ from ecosystem-scale CUE $\left(\mathrm{CUE}_{\mathrm{E}}\right) . \mathrm{CUE}_{\mathrm{C}}$ primarily integrates drivers that result in gross biomass production before biomass turnover or any process that detracts from production. Conversely, $\mathrm{CUE}_{\mathrm{E}}$ is a

$\mathrm{CUE}_{\mathrm{C}}$
Community-scale efficiency of microbial biomass synthesis
$\mathrm{CUE}_{C}=\frac{\text { gross biomass production }}{\text { substrate uptake }}$
Ranges from 0 to 1
Ignores recursive dynamics of decomposition like biomass
turnover and substrate recycling
Quantified by existing CUE methods ${ }^{\mathrm{a}}$ involving short (e.g.,
hourly) incubations after substrate amendment
Valuable for examining metabolic response of natural
microbial communities to substrates over short time scales
(hours)

measure of net biomass production (growth) reflecting all drivers of microbial efficiency, even those acting over longer time scales such as biomass turnover and recycling of necromass and exudates
$\mathrm{CUE}_{\mathrm{E}}$

Ecosystem-scale efficiency of microbial biomass synthesis and recycling of necromass/exudates

$\mathrm{CUE}_{E}=\frac{\text { net biomass production }}{\text { substrate uptake }}$

Ranges from 0 to 1

Incorporates the effects of biomass turnover, substrate recycling, and organo-mineral interactions

Rarely measured, although quantifiable through use of longer incubation periods

Valuable as an ecosystem-level measure of carbon stabilization within microbial biomass over long time scales (days to months)

a CUE methods here defined to include the most common substrate-based, growth rate-based, biomass-based, and uptake-based procedures. See Manzoni et al. (2012) for further description

generation is captured by the technique employed, and (2) $\mathrm{CUE}_{\mathrm{C}}$ values range between 0 and 1 , as gross production must be either zero or positive. A positive $\mathrm{CUE}_{\mathrm{C}}$ is interpreted as the presence of production, while a value of zero indicates a lack of production. Although the calculation of $\mathrm{CUE}_{C}$ is the same as $\mathrm{CUE}_{\mathrm{P}}$, estimates of the former are generally similar or smaller in magnitude because of the suboptimal biosynthetic conditions likely to be experienced outside of pure culture (Fig. 2).

Interpretation of $\mathrm{CUE}_{\mathrm{C}}$ values is critically dependent on time, specifically the sequential progression of processes that occur during substrate breakdown (Fig. 3). $\mathrm{CUE}_{\mathrm{C}}$ should theoretically change with time following, for example, a pulsed organic matter amendment to reflect (1) an initial increase and peak in efficiency due to rapid uptake without substantial respiratory losses, followed by (2) a decline in efficiency due to accumulating $\mathrm{C}$ loss pathways (Eq. 1). Consequently, methods using very short incubation times are likely to overestimate CUE because they integrate uptake dynamics more so than complete metabolism (Nguyen and Guckert 2001; Hill et al. 2008; Sinsabaugh et al. 2013). On the other hand, incubations that are too long may integrate the effects of biomass turnover and substrate recycling. Accurate interpretation of $\mathrm{CUE}_{\mathrm{C}}$ estimates therefore depends upon a relatively narrow window of incubation time such that complete metabolism, but not substrate recycling, is captured.

$C U E_{E}$

The observation period of $\mathrm{CUE}_{\mathrm{C}}$ methods leaves the ultimate fate of uptake carbon over time scales beyond the lifespan of an individual organism (days to weeks) undetermined. For instance, high $\mathrm{CUE}_{\mathrm{C}}$ estimates may not necessarily translate to long-term $\mathrm{C}$ retention as microbial biomass under scenarios where biomass rapidly turns over and necromass is not readily recycled. A third definition of CUE becomes necessary in order to account for the drivers that become significant beyond the conventional incubation times of $\mathrm{CUE}_{\mathrm{C}}$. We propose an ecosystem perspective of carbon use efficiency $\left(\mathrm{CUE}_{\mathrm{E}}\right)$ that integrates drivers originating from population and community scales, as well as time-dependent factors such as biomass turnover and the recycling of necromass and exudates that occur external to the cell. $\mathrm{CUE}_{\mathrm{E}}$ is thus a measure of the efficiency of substrate retention as microbial biomass through biosynthesis (i.e., $\mathrm{CUE}_{\mathrm{P}}$ and $\mathrm{CUE}_{\mathrm{C}}$ ) plus the efficiency of substrate recycling across generations of cells.

Because $\mathrm{CUE}_{\mathrm{E}}$ integrates the effects of extracellular substrate recycling, the role of the extracellular environment becomes important at this scale. Microbial exudates and necromass are exposed to various 


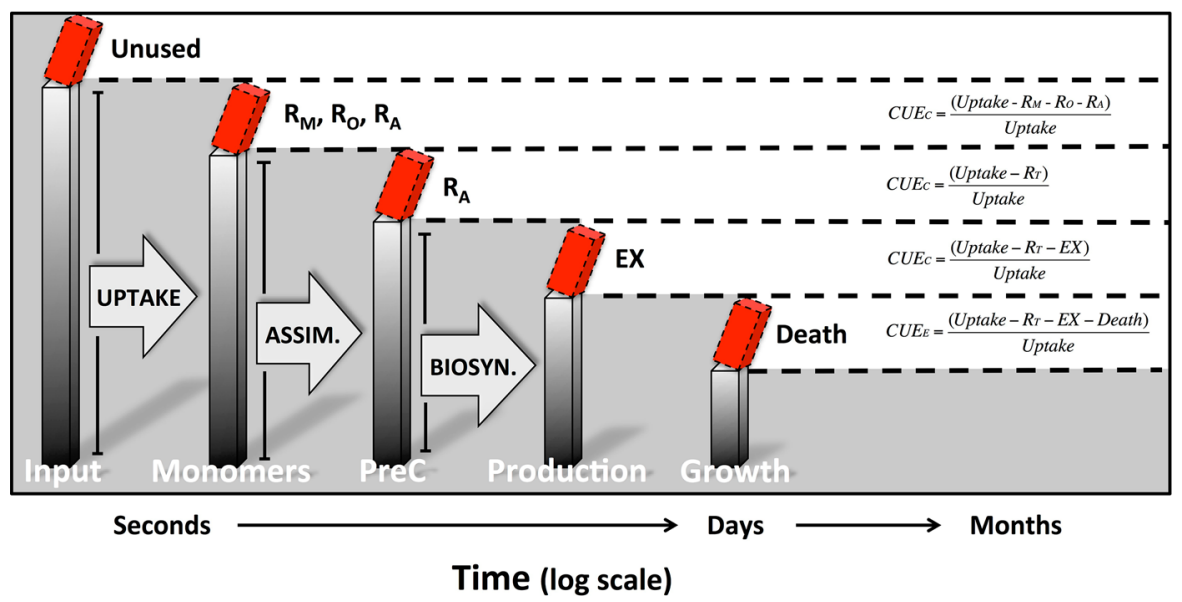

Fig. 3 Illustration of the accumulating loss terms that occur over time for a given unit of metabolized organic matter and the expected effect on carbon use efficiency $\left(\mathrm{CUE}_{\mathrm{C}}\right.$, but also $\mathrm{CUE}_{\mathrm{P}}$ ). Boxes represent pools of carbon and arrows represent the transformations that convert carbon into new forms. For example, of the total theoretical input of carbon to a system, the cell will take up a portion while the balance remains unused. Of the carbon that is taken up by cell (now defined as monomers), a

interactions with soil or sediment surfaces depending on soil texture and mineralogy (Fig. 1). These interactions may directly inhibit recycling by promoting formation of stable aggregates and organo-mineral associations, or can indirectly affect substrate stoichiometry through selective stabilization of some substrates, such as nitrogen-bearing compounds in clayey soils (Grandy et al. 2009; Cotrufo et al. 2013). CUE $\mathrm{E}_{\mathrm{E}}$ therefore depends on the uptake and metabolism of substrates that are likely changing in quality with time.

Using the terminology proposed here (Table 1), the mathematical definition of $\mathrm{CUE}_{\mathrm{E}}$ is (Eq. 2):

$$
\begin{aligned}
\mathrm{CUE}_{\mathrm{E}} & =\text { Growth } / \text { Uptake } \\
& =\left(\text { Uptake }-\mathrm{R}_{\mathrm{T}}-\mathrm{EX}-\text { Death }\right) / \text { Uptake } \\
& \left.=\text { Growth } / \text { (Production }+\mathrm{R}_{\mathrm{T}}+\mathrm{EX}\right) .
\end{aligned}
$$

Important characteristics of this formula are that: (1) growth represents the net microbial biomass production resulting from all interacting ecosystem forces acting over space and time, and (2) $\mathrm{CUE}_{\mathrm{E}}$ values can range between 0 and 1. The interpretation of $\mathrm{CUE}_{\mathrm{E}}$ is significantly different from scales of $\mathrm{CUE}_{\mathrm{P}}$ and $\mathrm{CUE}_{\mathrm{C}}$. A positive value suggests net accrual of uptake carbon as microbial biomass despite biomass losses, and zero indicates no uptake $\mathrm{C}$ remains in the microbial biomass pool. portion is assimilated into precursor compounds (PreC) necessary for biosynthesis while the remainder is dissimilated as maintenance respiration $\left(R_{M}\right)$, overflow respiration $\left(R_{O}\right)$, or anabolic respiration $\left(\mathrm{R}_{\mathrm{A}}\right)$. CUE declines as metabolism progresses and becomes $\mathrm{CUE}_{\mathrm{E}}$, or the net growth after timedependent losses such as biomass turnover (Death). $R_{T}$ total respiration; $E X$ exudates

Measuring microbial growth (net biosynthesis) is distinct from production (gross biosynthesis) in important ways. Short incubations $(<3 \mathrm{~h})$ following substrate addition more closely estimate microbial production, yet growth of the community could be zero for the same sample because of biomass turnover. Should CUE incubations be allowed to progress beyond the normal turnover time of microbes, techniques are more likely to reveal growth dynamics of the microbial community. Choosing an appropriate incubation duration that either captures or excludes biomass turnover and substrate recycling may be best decided from the average residence time of substrates in microbial biomass, or the average turnover rate of microbial cells. Hill et al. (2008) found glucose uptake to occur within $30 \mathrm{~s}$ of introduction but $6-8 \mathrm{~h}$ was the average residence time in microbial tissue. The average turnover rate of (soil) bacterial or fungal cells ranges from hours to days and from days to weeks, respectively (Rousk and Baath 2011). Incubations extending beyond $24-48 \mathrm{~h}$ are thus increasingly likely to reflect the effects of biomass turnover and substrate recycling on CUE estimates.

$\mathrm{CUE}_{\mathrm{E}}$ values integrate all of the factors subsumed by $\mathrm{CUE}_{\mathrm{C}}$ but also include the effects of cell death and the efficiency of necromass and exudate recycling. $\mathrm{CUE}_{\mathrm{E}}$ estimates should thus be lower than $\mathrm{CUE}_{\mathrm{C}}$ 


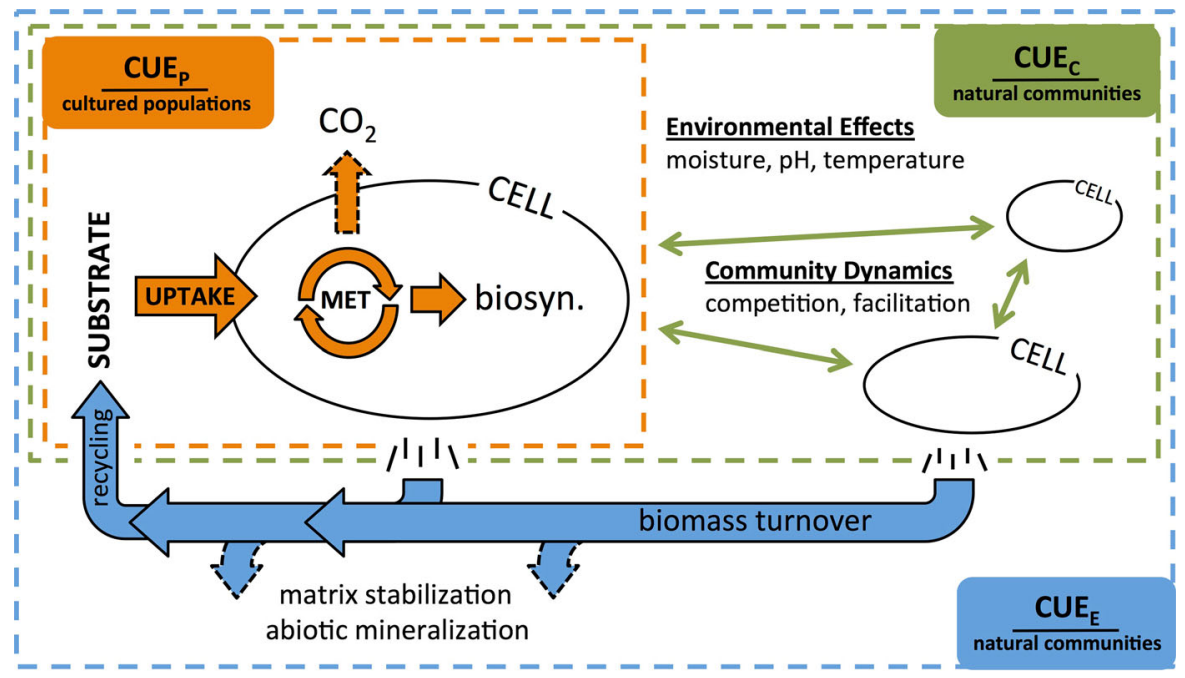

Fig. 4 Microbial carbon use efficiency partitioned into three nested definitions that integrate increasingly broad temporal and spatial drivers of efficiency. $\mathrm{CUE}_{\mathrm{P}}$ reflects the species-specific functioning of microbial taxa (e.g., biosynthesis rate, exudate production) and thermodynamics of carbon substrate metabolism (MET) that limit the proportion of uptake carbon used for biosynthesis versus lost from the cell (e.g., mineralized or exuded as metabolites). CUE $\mathrm{P}_{\mathrm{P}}$ is generally measured on cultured populations. $\mathrm{CUE}_{\mathrm{C}}$ is measured on natural (aquatic or soil)

because these additional processes act to reduce microbial biomass production from gross to net values. For example, a discrete quantity of hypothetical organic C (e.g., from a pulse input of fine root tissue to soil, or an amendment of isotopically-labeled substrate) may initially be metabolized to yield a $\mathrm{CUE}_{\mathrm{C}}$ estimate of 0.6 but become an apparent $\mathrm{CUE}_{\mathrm{E}}$ of 0.4 upon cell death. This necromass may then interact with the extracellular environment, where recycling of substrates by neighboring cells must compete with processes like stabilization on mineral surfaces or aggregate formation that prevent their reuse. Even if all necromass and exudates are perfectly $(100 \%)$ recovered, however, respiratory losses will again result in $\mathrm{C}$ loss during each iterative round of metabolism (here by $40 \%$ ). This simplified scenario illustrates how $\mathrm{CUE}_{\mathrm{E}}$ estimates must decline over time; indeed experimental evidence has shown reduced apparent CUE in the presence of microbial grazing (Frey et al. 2001; Ram et al. 2003) and over extended incubations (Elliott et al. 1983; Hunt et al. 1985; Blagodatskaya et al. 2014). $\mathrm{CUE}_{\mathrm{E}}$ may ultimately approach zero as all of the hypothetical $\mathrm{C}$ is eventually lost from microbial biomass as respired communities and thus accounts for additional environmental and community drivers that affect microbial metabolism. Existing methodologies largely restrict $\mathrm{CUE}_{\mathrm{C}}$ to reflect gross microbial production before recursive substrate recycling of necromass and exudates (dashed lines leading from cells). $\mathrm{CUE}_{\mathrm{E}}$ describes long-term (e.g., days to months) carbon retention as net microbial growth due to $\mathrm{CUE}_{\mathrm{P}}$ and $\mathrm{CUE}_{\mathrm{C}}$, but also the efficiency of substrate recycling among generations of cells

$\mathrm{CO}_{2}$, humified stable organic matter, or been propagated up the food chain.

The declining pattern of $\mathrm{CUE}_{\mathrm{E}}$ should not marginalize its value for understanding the many pathways and bottlenecks of microbial organic matter breakdown. The decline may occur over a period of days or decades depending on the net effect of substrate recycling and opposing processes like mineral stabilization, yet in either case vital information is at hand. For example, a $\mathrm{CUE}_{\mathrm{E}}$ value that descends rapidly to zero with time may indicate quick biomass turnover and/or little capacity for substrate recycling because of strong organo-mineral interactions that restrict substrate bioavailability. Microbes under such a condition would require ample exogenous resources in order to remain at steady state biomass concentrations and may respire heavily or commit large amounts of necromass or exudates to a stable, biologically unavailable, organic matter pool. On the other hand, relatively high $\mathrm{CUE}_{\mathrm{E}}$ values suggest a more "selfsustaining" microbial biomass that efficiently retains C within biologically active biomass pools. The biomass turnover and recycling dynamics inherent to an ecosystem perspective of CUE thus provide an 
important perspective to the debate over how changing microbial CUE may affect global carbon stocks (Frey et al. 2013; Allison 2014).

\section{Summary and future directions}

We believe our conceptual model of CUE enhances the interpretability of existing estimates by drawing together, and creating order from, the biological and methodological components of various research perspectives (Fig. 4). Researchers may ultimately choose a $\mathrm{CUE}_{\mathrm{P}}, \mathrm{CUE}_{\mathrm{C}}$, or $\mathrm{CUE}_{\mathrm{E}}$ approach to address a specific question, but must be cognizant of the inherent limitations that each possesses as intrinsic, absolute, and apparent measures of carbon use efficiency, respectively (Table 2). CUE $\mathrm{P}_{\mathrm{P}}$ estimates provide the most accurate indication of taxon-specific, genetically constrained physiological limits to metabolism that intrinsically affects CUE at any scale of observation. Alternatively, if the natural environmental and community effects on efficiency are of interest, a variety of $\mathrm{CUE}_{\mathrm{C}}$ techniques using labeled and unlabeled substrates and calorespirometry exist (Fig. 2). These approaches provide valuable measures of the absolute efficiency achieved by complex communities during metabolism of substrates immediately upon uptake, given existing conditions for biosynthesis. Importantly, these methods largely ignore the biomass turnover and substrate recycling that affect gross biomass production. The ecosystem perspective of $\mathrm{CUE}_{\mathrm{E}}$ integrates all relevant drivers in order to describe the apparent efficiency of microbial processing of $\mathrm{C}$ that results from all interacting population, community, and ecosystem-scale constraints.

Microbial CUE will become a more broadly interpretable and easily communicated concept as efforts to synthesize available data are made and a standardized terminology is employed. We make the following suggestions to immediately and directly improve the collective conversation surrounding microbial efficiency.

(1) Use of consistent terminology Foremost, a standard vocabulary regarding carbon use efficiency is necessary groundwork in order for discipline-specific findings to be both accessible and usable by the broader scientific community.
More careful use of language should be a particular concern in order to avoid miscommunication and confusion. Our conceptual approach uses well-defined terminology amenable to a range of research interests (Table 1) and we hope that future work will use these suggestions with an eye towards standardization. The terms $\mathrm{CUE}_{\mathrm{P}}, \mathrm{CUE}_{\mathrm{C}}$, and $\mathrm{CUE}_{\mathrm{E}}$ also conveniently organize the important drivers of efficiency and the most commonly used methods by scale of inference (Fig. 2).

(2) Recognition of methodological assumptions Researchers must be aware of the full breadth of assumptions and limitations inherent to various techniques, particularly when attempting to compare efficiency estimates that do not share the same methods. Unfortunately the full scope of assumptions associated with most methods is still unrealized, and thus only a "best guess" can be given as to what a particular efficiency estimate truly represents. For instance, whether exudate generation and biomass turnover have been accounted for will vary between techniques that differ in substrate incubation lengths. Careful choice of the proper experimental approach can help reduce the number of assumptions that often qualify results.

(3) Comparison of methods A comprehensive experimental comparison of available techniques for measuring microbial efficiency has not been done. Thus, any variability in efficiency estimates produced by different methodological approaches should not be explained as due to ecological factors until inherent differences in methods have been fully explored. For instance, a recently described divergence in CUE for aquatic and terrestrial systems (e.g., $\sim 0.3$ and $\sim 0.6$, respectively) (Manzoni et al. 2012; Sinsabaugh et al. 2013) may be a biological consequence of how microorganisms perceive heterogeneous (soil) versus potentially more homogenous (aquatic) environments. Alternatively, aquatic methods may simply generate lower efficiency estimates because incorporation of substrates into proteins or nucleic acids infers direct biosynthesis by a cell (Alden et al. 2001), whereas methods applied to soils typically denote the broader process of 
substrate uptake where internalized substrate may be used for biosynthesis or be passively stored (Payne and Wiebe 1978). The lack of a comprehensive methods comparison also perpetuates a culture of using only "in-house" techniques for measuring efficiency rather than objective choices among available methods. Methods transparency will better permit researchers to select the technique that best matches their particular scale of inquiry.

(4) Measurement of the extracellular forces shaping $C U E_{E}$ Many factors play a role in determining the ultimate proportion of metabolized $\mathrm{C}$ that becomes stabilized as microbial biomass. Beyond the short-term controls associated with microbial physiology, numerous properties such as exudate generation, biomass turnover, and substrate recycling become highly influential over time scales of days to months (Fig. 3). The mechanisms by which these factors influence efficiency are poorly understood and will require additional attention. For instance, at what rate are exudates produced under different biosynthetic conditions (Kawasaki and Benner 2006), and what is the long-term fate of these compounds? The regulatory control of soil or sediment mineralogy, or any environmental matrix, in making organic matter available for decomposition is an important yet underexplored step in $\mathrm{CUE}_{\mathrm{E}}$ (Schmidt et al. 2011). Long-term radioisotope experiments have indicated that most substrate $\mathrm{C}$ is lost rapidly from soils in the first year of decomposition, but $\sim 20 \%$ may persist up to a decade later (Jenkinson 1968; Sorensen 1987; Voroney et al. 1989) as stable soil organic matter. Some organic matter is thus likely to remain subject to microbial processing and reprocessing for years.

(5) Use of CUE estimates in modeling Simulation models of $\mathrm{C}$ cycling generally represent microbes implicitly by including static, timeinvariant values of microbial efficiency that determine net $\mathrm{C}$ movement between pools after losses (Parton et al. 1987; Vallino et al. 1996). At this scale, efficiency is conceptually most closely related to $\mathrm{CUE}_{\mathrm{E}}$. However, $\mathrm{CUE}_{\mathrm{E}}$ is a time-dependent system property that integrates a variety of processes. Given this, it is unsurprising that ecosystem $\mathrm{C}$ models are sensitive to values of CUE and that so many reasonable but widely distributed recommendations exist for the appropriate estimates to use (del Giorgio and Newell 2012; Moorhead et al. 2012; Frey et al. 2013; Allison 2014). Moving forward, soil C models can avoid many of these concerns by explicitly representing microbial activity and the processes that cause ecosystem-level measures of CUE to diverge. Some are beginning to do this: the microbial-mineral carbon stabilization (MIMICS) model, for example, explicitly represents microbial $\mathrm{C}$ processing and incorporates efficiency values at the level of $\mathrm{CUE}_{\mathrm{C}}$ (Wieder et al. 2014). Efficiency values in MIMICS are time-invariant, but the structure of the model allows for recursive processing of $\mathrm{C}$ through microbial biomass. Other recent models include efficiency parameters that conceptually match $\mathrm{CUE}_{\mathrm{C}}$ but depict additional microbial processes like substrate recycling and dormancy not generally captured in $\mathrm{CUE}_{\mathrm{C}}$ measurements [microbial-enzyme-mediated decomposition model, MEND (Wang et al. 2013); Extracellular EnZYme model, EEZY (Moorhead et al. 2012)]. Because CUE $_{\mathrm{E}}$ collapses all of the ecosystem-wide controls over microbial efficiency into a single number, it may not be valuable in explicit models where all drivers of CUE are individually represented. However, $\mathrm{CUE}_{\mathrm{E}}$ measurements may serve to assess the accuracy of outcomes from such models.

(6) Collaboration We hope that the framework proposed here will stimulate efforts for collaboration among researchers by providing a standard vocabulary and a means of interpreting efficiency estimates that come from dissimilar techniques and/or focus on different habitats. Collaboration will also encourage discussion about the merits of various approaches for quantifying efficiency and may lead to quicker methodological advancements. Many of the challenges and limitations discussed here will be best addressed through combined efforts from all of the disciplines that actively contribute to our understanding of microbial efficiency. 
Acknowledgments Funding was provided by a grant (Hatch 1003421) from the USDA National Institute of Food and Agriculture through the New Hampshire Agricultural Experiment Station (NH-AES), and USDA grants 67019-21716 (2014) and 35615-22747 (2015). This is NHAES Scientific Contribution Number 2615. We thank four anonymous reviewers for improving this manuscript with their constructive comments.

\section{Compliance with ethical standards}

Conflict of Interest The authors declare that they have no conflict of interest.

Open Access This article is distributed under the terms of the Creative Commons Attribution 4.0 International License (http:// creativecommons.org/licenses/by/4.0/), which permits unrestricted use, distribution, and reproduction in any medium, provided you give appropriate credit to the original author(s) and the source, provide a link to the Creative Commons license, and indicate if changes were made.

\section{References}

Alden L, Demoling F, Baath E (2001) Rapid method of determining factors limiting bacterial growth in soil. Appl Environ Microbiol 67:1830-1838

Allison SD (2014) Modeling adaptation of carbon use efficiency in microbial communities. Front Microbiol 5:9

Amado AM, Meirelles-Pereira F, Vidal LO, Sarmento H, Suhett AL, Farjalla VF, Cotner JB, Roland F (2013) Tropical freshwater ecosystems have lower bacterial growth efficiency than temperate ones. Front Microbiol 4:8

Angulo-Brown F, Santillan M, Callejaquevedo E (1995) Thermodynamic optimality in some biochemical reactions. Nuovo Cimento Soc Ital Fis D-Condens Matter At Mol Chem Phys Fluids Plasmas Biophys 17:87-90

Apple JK, del Giorgio P (2007) Organic substrate quality as the link between bacterioplankton carbon demand and growth efficiency in a temperate salt-marsh estuary. ISME J 1:729-742

Apple JK, del Giorgi PA, Kemp WM (2006) Temperature regulation of bacterial production, respiration, and growth efficiency in a temperate salt-marsh estuary. Aquat Microb Ecol 43:243-254

Babel W (2009) The Auxiliary Substrate Concept: from simple considerations to heuristically valuable knowledge. Eng Life Sci 9:285-290

Barros N, Salgado J, Rodriguez-Anon JA, Proupin J, Villanueva M, Hansen LD (2010) Calorimetric approach to metabolic carbon conversion efficiency in soils. J Therm Anal Calorim 99:771-777

Blagodatskaya E, Blagodatsky S, Anderson TH, Kuzyakov Y (2014) Microbial growth and carbon use efficiency in the rhizosphere and root-free soil. PLoS One 9:9

Blazewicz SJ, Schwartz E (2011) Dynamics of O-18 incorporation from $\mathrm{H}$ (2) (18) O into soil microbial DNA. Microb Ecol 61:911-916
Bol R, Poirier N, Balesdent J, Gleixner G (2009) Molecular turnover time of soil organic matter in particle-size fractions of an arable soil. Rapid Commun Mass Spectrom 23:2551-2558

Bott T (2006) Primary productivity and community respiration. In: Hauer FR, Lamberti GA (eds) Methods in stream ecology. Academic Press, Cambridge, pp 663-690

Brant JB, Sulzman EW, Myrold DD (2006) Microbial community utilization of added carbon substrates in response to long-term carbon input manipulation. Soil Biol Biochem 38:2219-2232

Bremer E, Kuikman P (1994) Microbial utilization of C-14 U glucose in soil is affected by the amount and timing of glucose additions. Soil Biol Biochem 26:511-517

Cole JJ, Findlay S, Pace ML (1988) Bacterial production in fresh and saltwater ecosystems - a cross-system overview. Mar Ecol Prog Ser 43:1-10

Cotrufo MF, Wallenstein MD, Boot CM, Denef K, Paul E (2013) The microbial efficiency-matrix stabilization (MEMS) framework integrates plant litter decomposition with soil organic matter stabilization: do labile plant inputs form stable soil organic matter? Glob Change Biol 19:988-995

Creamer CA, Jones DL, Baldock JA, Farrell M (2014) Stoichiometric controls upon low molecular weight carbon decomposition. Soil Biol Biochem 79:50-56

Dawes EA, Ribbons DW (1964) Some aspects of endogenous metabolism of bacteria. Bacteriol Rev 28:126

del Giorgio PA, Cole JJ (1998) Bacterial growth efficiency in natural aquatic systems. Annu Rev Ecol Syst 29:503-541

del Giorgio PA, Newell REI (2012) Phosphorus and DOC availability influence the partitioning between bacterioplankton production and respiration in tidal marsh ecosystems. Environ Microbiol 14:1296-1307

Devevre OC, Horwath WR (2000) Decomposition of rice straw and microbial carbon use efficiency under different soil temperatures and moistures. Soil Biol Biochem 32:1773-1785

Dijkstra P, Blankinship JC, Selmants PC, Hart SC, Koch GW, Schwartz E, Hungate BA (2011a) Probing carbon flux patterns through soil microbial metabolic networks using parallel position-specific tracer labeling. Soil Biol Biochem 43:126-132

Dijkstra P, Dalder JJ, Selmants PC, Hart SC, Koch GW, Schwartz E, Hungate BA (2011b) Modeling soil metabolic processes using isotopologue pairs of position-specific C-13-labeled glucose and pyruvate. Soil Biol Biochem 43:1848-1857

Dijkstra P, Thomas SC, Heinrich PL, Koch GW, Schwartz E, Hungate BA (2011c) Effect of temperature on metabolic activity of intact microbial communities: evidence for altered metabolic pathway activity but not for increased maintenance respiration and reduced carbon use efficiency. Soil Biol Biochem 43:2023-2031

Elliott ET, Cole CV, Fairbanks BC, Woods LE, Bryant RJ, Coleman DC (1983) Short-term bacterial growth, nutrient uptake, and ATP turnover in sterilized, inoculated and $\mathrm{C}$-amended soil - the influence of $\mathrm{N}$ availability. Soil Biol Biochem 15:85-91

Fonte ES, Amado AM, Meirelles-Pereira F, Esteves FA, Rosado AS, Farjalla VF (2013) The combination of different 
carbon sources enhances bacterial growth efficiency in aquatic ecosystems. Microb Ecol 66:871-878

Frey SD, Gupta V, Elliott ET, Paustian K (2001) Protozoan grazing affects estimates of carbon utilization efficiency of the soil microbial community. Soil Biol Biochem 33:1759-1768

Frey S, Lee J, Melillo JM, Six J (2013) The temperature response of soil microbial efficiency and its feedback to climate. Nat Clim Change 3:395-398

Fuhrman JA, Azam F (1980) Bacterioplankton secondary production estimates for coastal waters of British-Colombia, Antarctica, and California. Appl Environ Microbiol 39:1085-1095

Gommers PJF, Vanschie BJ, Vandijken JP, Kuenen JG (1988) Biochemical limits to microbial growth yields-an analysis of mixed substrate utilization. Biotechnol Bioeng 32:86-94

Grandy AS, Strickland MS, Lauber CL, Bradford MA, Fierer N (2009) The influence of microbial communities, management, and soil texture on soil organic matter chemistry. Geoderma 150:278-286

Hagerty S, van Groenigen KJ, Allison SD, Hungate BA, Schwartz E, Koch GW, Kolka RK, Dijkstra P (2014) Accelerated microbial turnover but constant growth efficiency with warming in soil. Nat Clim Change 4:903-906

Harris JA, Ritz K, Coucheney E, Grice SM, Lerch TZ, Pawlett M, Herrmann AM (2012) The thermodynamic efficiency of soil microbial communities subject to long-term stress is lower than those under conventional input regimes. Soil Biol Biochem 47:149-157

Herrmann AM, Coucheney E, Nunan N (2014) Isothermal microcalorimetry provides new insight into terrestrial carbon cycling. Environ Sci Technol 48:4344-4352

Hill PW, Farrar JF, Jones DL (2008) Decoupling of microbial glucose uptake and mineralization in soil. Soil Biol Biochem 40:616-624

Hunt HW, Cole CV, Elliott ET (1985) Models for growth of bacteria inoculated into sterilized soil. Soil Sci 139:156-165

Ingraham JL, Maaloe O, Neidhardt FC (1983) Growth of the bacterial cell. Sinauer Associates Inc, Sunderland

Jenkinson DS (1968) Turnover of organic matter in soil. Biochem J 109:P2

Karhu K, Auffret MD, Dungait JAJ, Hopkins DW, Prosser JI, Singh BK, Subke JA, Wookey PA, Agren GI, Sebastia MT, Gouriveau F, Bergkvist G, Meir P, Nottingham AT, Salinas N, Hartley IP (2014) Temperature sensitivity of soil respiration rates enhanced by microbial community response. Nature 513:81

Kawasaki N, Benner R (2006) Bacterial release of dissolved organic matter during cell growth and decline: molecular origin and composition. Limnol Oceanogr $51: 2170-2180$

Keiblinger KM, Hall EK, Wanek W, Szukics U, Hammerle I, Ellersdorfer G, Bock S, Strauss J, Sterflinger K, Richter A, Zechmeister-Boltenstern S (2010) The effect of resource quantity and resource stoichiometry on microbial carbonuse-efficiency. FEMS Microbiol Ecol 73:430-440

Kim B, Gadd G (2008) Bacterial physiology and metabolism. Cambridge University Press, New York

Kosolapov DB, Kosolapova NG, Rumyantseva EV (2014) Activity and growth efficiency of heterotrophic bacteria in Rybinsk Reservoir. Biol Bull 41:324-332
Kredics L, Antal Z, Manczinger L (2000) Influence of water potential on growth, enzyme secretion and in vitro enzyme activities of Trichoderma harzianum at different temperatures. Curr Microbiol 40:310-314

Lee ZM, Schmidt TM (2014) Bacterial growth efficiency varies in soils under different land management practices. Soil Biol Biochem 69:282-290

Lemee R, Rochelle-Newall E, Van Wambeke F, Pizay MD, Rinaldi P, Gattuso JP (2002) Seasonal variation of bacterial production, respiration and growth efficiency in the open NW Mediterranean Sea. Aquat Microb Ecol 29:227-237

Lindeman RL (1942) The trophic-dynamic aspect of ecology. Ecology 23:399-418

Linton JD, Stephenson RJ (1978) A preliminary study on growth yields in relation to carbon and energy content of various organic growth substrates. FEMS Microbiol Lett 3:95-98

Lipson DA, Monson RK, Schmidt SK, Weintraub MN (2009) The trade-off between growth rate and yield in microbial communities and the consequences for under-snow soil respiration in a high elevation coniferous forest. Biogeochemistry 95:23-35

Manzoni S, Jackson RB, Trofymow JA, Porporato A (2008) The global stoichiometry of litter nitrogen mineralization. Science 321:684-686

Manzoni S, Taylor P, Richter A, Porporato A, Agren GI (2012) Environmental and stoichiometric controls on microbial carbon-use efficiency in soils. New Phytol 196:79-91

Marr AG, Nilson EH, Clark DJ (1963) The maintenance requirement of Escherichia coli. Ann N Y Acad Sci 102:548

Moorhead DL, Lashermes G, Sinsabaugh RL (2012) A theoretical model of $\mathrm{C}$ - and $\mathrm{N}$-acquiring exoenzyme activities, which balances microbial demands during decomposition. Soil Biol Biochem 53:133-141

Mooshammer M, Wanek W, Zechmeister-Boltenstern S, Richter A (2014) Stoichiometric imbalances between terrestrial decomposer communities and their resources: mechanisms and implications of microbial adaptations to their resources. Front Microbiol 5:10

Neidhardt FC, Ingraham JL, Schaechter M (1990) Physiology of the bacterial cell: a molecular approach. Sinauer Associates Inc, Sunderland

Nguyen C, Guckert A (2001) Short-term utilisation of C-14 U glucose by soil microorganisms in relation to carbon availability. Soil Biol Biochem 33:53-60

Ortega-Retuerta E, Jeffrey WH, Babin M, Belanger S, Benner R, Marie D, Matsuoka A, Raimbault P, Joux F (2012) Carbon fluxes in the Canadian Arctic: patterns and drivers of bacterial abundance, production and respiration on the Beaufort Sea margin. Biogeosciences 9:3679-3692

Parton WJ, Schimel DS, Cole CV, Ojima DS (1987) Analysis of factors controlling soil organic matter levels in Great Plains grasslands USA. Soil Sci Soc Am J 51:1173-1179

Paustian K, Robertson GP, Elliott ET (1995) Management impacts on carbon storage and gas fluxes $(\mathrm{CO} 2, \mathrm{CH} 4)$ in mid-latitude cropland. In: Lal R, Kimble JM, Levine E, Stewart BA (eds) Soil management and the greenhouse effect. CRC Press, Boca Raton, pp 69-84

Payne WJ, Wiebe WJ (1978) Growth yield and efficiency in chemosynthetic microorganisms. Annu Rev Microbiol 32:155-183 
Pfeiffer T, Schuster S, Bonhoeffer S (2001) Cooperation and competition in the evolution of ATP-producing pathways. Science 292:504-507

Pirt SJ (1965) The maintenance energy of bacteria in growing cultures. Proc R Soc Lond Ser B-Biol Sci 163:224-231

Ram ASP, Nair S, Chandramohan D (2003) Bacterial growth efficiency in the tropical estuarine and coastal waters of Goa, southwest coast of India. Microb Ecol 45:88-96

Reischke S, Rousk J, Baath E (2014) The effects of glucose loading rates on bacterial and fungal growth in soil. Soil Biol Biochem 70:88-95

Rivkin RB, Legendre L (2001) Biogenic carbon cycling in the upper ocean: effects of microbial respiration. Science 291:2398-2400

Roels JA (1980) Application of macroscopic principles to microbial metabolism. Biotechnol Bioeng 22:2457-2514

Roller BRK, Schmidt TM (2015) The physiology and ecological implications of efficient growth. Int Soc Microb Ecol 9:1481-1487. doi:10.1038/ismej.2014.235

Rousk J, Baath E (2007) Fungal and bacterial growth in soil with plant materials of different $\mathrm{C} / \mathrm{N}$ ratios. FEMS Microbiol Ecol 62:258-267

Rousk J, Baath E (2011) Growth of saprotrophic fungi and bacteria in soil. FEMS Microbiol Ecol 78:17-30

Russell JB, Cook GM (1995) Energetics of bacterial growthbalance of anabolic and catabolic reactions. Microbiol Rev 59:48-62

Schipper LA, Hobbs JK, Rutledge S, Arcus VL (2014) Thermodynamic theory explains the temperature optima of soil microbial processes and high $\mathrm{Q}(10)$ values at low temperatures. Glob Change Biol 20:3578-3586

Schmidt MWI, Torn MS, Abiven S, Dittmar T, Guggenberger G, Janssens IA, Kleber M, Koegel-Knabner I, Lehmann J, Manning DAC, Nannipieri P, Rasse DP, Weiner S, Trumbore SE (2011) Persistence of soil organic matter as an ecosystem property. Nature (London) 478:49-56

Sinsabaugh RL, Manzoni S, Moorhead DL, Richter A (2013) Carbon use efficiency of microbial communities: stoichiometry, methodology and modelling. Ecol Lett 16:930-939

Six J, Frey SD, Thiet RK, Batten KM (2006) Bacterial and fungal contributions to carbon sequestration in agroecosystems. Soil Sci Soc Am J 70:555-569

Sorensen LH (1987) Organic-matter and microbial biomass in a soil incubated in the field for 20 years with C-14-labeled barley straw. Soil Biol Biochem 19:39-42
Tang YJ, Martin HG, Myers S, Rodriguez S, Baidoo EEK, Keasling JD (2009) Advances in analysis of microbial metabolic fluxes via C-13 isotopic labeling. Mass Spectrom Rev 28:362-375

Tang JKH, You L, Blankenship RE, Tang YJJ (2012) Recent advances in mapping environmental microbial metabolisms through C-13 isotopic fingerprints. J R Soc Interface 9:2767-2780

Tannler S, Decasper S, Sauer U (2008) Maintenance metabolism and carbon fluxes in Bacillus species. Microb Cell Fact 7:13

Thiet RK, Frey SD, Six J (2006) Do growth yield efficiencies differ between soil microbial communities differing in fungal: bacterial ratios? Reality check and methodological issues. Soil Biol Biochem 38:837-844

Tiemann LK, Billings SA (2011) Changes in variability of soil moisture alter microbial community $\mathrm{C}$ and $\mathrm{N}$ resource use. Soil Biol Biochem 43:1837-1847

Vallino JJ, Hopkinson CS, Hobbie JE (1996) Modeling bacterial utilization of dissolved organic matter: optimization replaces monod growth kinetics. Limnol Oceanogr 41:1591-1609

von Stockar U, Maskow T, Liu JS, Marison IW, Patino R (2006) Thermodynamics of microbial growth and metabolism: an analysis of the current situation. J Biotechnol 121:517-533

Voroney RP, Paul EA, Anderson DW (1989) Decomposition of wheat straw and stabilization of microbial products. Can J Soil Sci 69:63-77

Wang GS, Post WM (2012) A theoretical reassessment of microbial maintenance and implications for microbial ecology modeling. FEMS Microbiol Ecol 81:610-617

Wang GS, Post WM, Mayes MA (2013) Development of microbial-enzyme-mediated decomposition model parameters through steady-state and dynamic analyses. Ecol Appl 23:255-272

Ward A (2006) Heterotrophic bacteria. In: Hauer FR, Lamberti GA (eds) Methods in stream ecology. Academic Press, Cambridge, pp 293-309

Wieder WR, Grandy AS, Kallenbach CM, Bonan GB (2014) Integrating microbial physiology and physio-chemical principles in soils with the microbial-mineral carbon stabilization (MIMICS) model. Biogeosciences 11:3899-3917

Zhang YHP, Lynd LR (2005) Cellulose utilization by Clostridium thermocellum: bioenergetics and hydrolysis product assimilation. Proc Natl Acad Sci USA 102:7321-7325 